\title{
Multilingual education for European minority languages: The Basque Country and Friesland
}

\author{
Durk Gorter · Jasone Cenoz
}

Published online: 13 December 2011

(C) The Author(s) 2011. This article is published with open access at Springerlink.com

\begin{abstract}
Over the last three decades, regional minority languages in Europe have regained increased recognition and support. Their revitalisation is partly due to their being taught in schools. Multilingualism has special characteristics for speakers of minority languages and it poses unique challenges for learning minority languages. This article looks at the cases of Basque and Frisian, comparing and contrasting their similarities and differences. The educational system in the Basque Autonomous Community underwent an important transformation, starting in 1979 from a situation where less than 5 per cent of all teachers were capable of teaching through Basque. Today this figure has changed to more than 80 per cent. An innovative approach was chosen for teaching the minority language, Basque, alongside the dominant language, Spanish, and the international language, English. The outcome is a substantial increase in the proficiency in the minority language among the younger age groups. The decline of the minority language has thus been successfully reversed and one of the major challenges now is to uphold a sustainable educational system. By contrast, the Frisian language has fared less well in the Netherlands, where developments over the last 30 years have been much slower and the results more modest. Here policy-making for education and for language is caught in a continuous debate between a weak provincial level and a powerful central state level. Overall, multilingualism as a resource for individuals is valued for "bigger" languages such as English, French and German, but not for a "small" language such as Frisian. Nevertheless, a few trilingual experiments have been
\end{abstract}

D. Gorter $(\bowtie)$

Department of Theory and History of Education, FICE, IKERBASQUE, University of the Basque Country, Tolosa Hiribidea 70, 20018 Donostia-San Sebastián, Basque Country, Spain e-mail: d.gorter@ikerbasque.org

J. Cenoz

Department of Research Methods in Education, FICE, University of the Basque Country,

Tolosa Hiribidea 70, 20018 Donostia-San Sebastián, Basque Country, Spain

e-mail: jasone.cenoz@ehu.es 
carried out in some schools in Friesland in teaching Frisian, Dutch and English. These experiments may also be instructive for other cases of minority languages of a "moderate strength". In the cases of both Basque and Frisian multilingualism is generally perceived as an important resource.

Keywords Basque in France and Spain - Frisian in the Netherlands ·

Educational language policies · Models of language schooling ·

Outcomes of bilingual education - Trilingual education

Résumé Enseignement multilingue en faveur des langues minoritaires en Europe : Pays basque et Frise - Depuis trois décennies, les langues minoritaires régionales en Europe bénéficient d'un regain de reconnaissance et de soutien. Leur reviviscence est due en partie à ce qu'elles sont enseignées dans les établissements scolaires. Le multilinguisme revêt des caractéristiques spécifiques pour les locuteurs des langues minoritaires, et pose des défis propres à l'apprentissage de ces langues. Les auteurs de cet article analysent les cas du Pays basque et de la Frise, en comparant et opposant leurs similitudes et différences. Le système éducatif de la Communauté autonome du Pays basque a connu une importante transformation amorcée en 1979, alors que moins de 5 pour cent du corps enseignant était en mesure d'exercer en langue basque. Aujourd'hui, ce chiffre est passé à plus de 80 pour cent. Une approche innovante a été adoptée pour enseigner la langue minoritaire basque, parallèlement à la langue dominante, l'espagnol, et à la langue internationale, l'anglais. Le résultat est une amélioration considérable de la maîtrise du basque parmi les jeunes. L'ancien déclin de la langue minoritaire a ainsi été inversé avec succès, et l'un des défis majeurs aujourd'hui consiste à pérenniser ce système éducatif. En revanche, la langue frisonne a connu un destin moins radieux aux Pays-Bas, où les avancées au cours des 30 dernières années ont été beaucoup plus lentes et les résultats plus modestes. La conception des politiques éducatives et linguistiques est enlisée dans une controverse permanente entre une province faible et un État central puissant. Mais surtout, le multilinguisme appréhendé comme richesse individuelle est valorisé pour les «grandes » langues comme l'anglais, le français et l'allemand, et non pas pour une « petite » langue telle que le frison. Néanmoins, quelques expériences trilingues ont été tentées dans certaines écoles de la province de Frise avec l'enseignement du frison, du néerlandais et de l'anglais. Ces expériences peuvent être instructives pour d'autres langues minoritaires de «force moyenne ». Dans les deux cas du basque et du frison, le multilinguisme est ressenti de manière générale comme une précieuse ressource.

Zusammenfassung Mehrsprachige Bildung und europäische Minderheitensprachen: das Baskenland und Friesland - In den vergangenen drei Jahrzehnten wurde regionalen Minderheitensprachen in Europa wieder mehr Anerkennung und Unterstützung zuteil. Ihre Wiederbelebung ist teilweise darauf zurückzuführen, dass sie in Schulen unterrichtet werden. Für die Sprecher von Minderheitensprachen birgt die Mehrsprachigkeit einige Besonderheiten, und sie stellt zudem spezifische Anforderungen an den Erwerb von Minderheitensprachen. Dieser Artikel beschäftigt sich mit dem Baskenland und mit Friesland und arbeitet deren Ähnlichkeiten 
und Unterschiede heraus. Das Schulsystem im autonomen Baskenland hat einen enormen Wandlungsprozess hinter sich. Dieser begann 1979 in einer Zeit, in der weniger als 5 Prozent aller Lehrkräfte in der Lage waren, ihren Unterricht in baskischer Sprache zu erteilen. Heute ist deren Zahl auf über 80 Prozent gestiegen. Für den Unterricht in der Minderheitensprache Baskisch, neben dem dominanten Spanisch und dem internationalen Englisch, wurde ein innovativer Ansatz gewählt. Dies hat dazu geführt, dass die jüngeren Altersgruppen die Minderheitensprache heute erheblich besser beherrschen. Der Niedergang der Minderheitensprache wurde somit erfolgreich umgekehrt, und eine der wichtigsten Aufgaben ist nunmehr die Gestaltung eines zukunftsfähigen Bildungssystems. Im Gegensatz dazu war der friesischen Sprache in den Niederlanden weniger Erfolg beschieden. Dort haben sich die Dinge in den letzten 30 Jahren viel langsamer entwickelt und die Ergebnisse sind bescheidener. Hier geraten Bildungspolitik und Sprachpolitik ständig zwischen die Fronten einer schwachen Provinzebene und eines mächtigen Zentralstaats. Insgesamt genießt die Mehrsprachigkeit als individuelle Kompetenz bei „großen“ Sprachen, wie zum Beispiel Englisch, Französisch und Deutsch, hohe Wertschätzung, nicht jedoch bei einer „kleinen“ Sprache wie Friesisch. Gleichwohl wurden in einigen Schulen Frieslands einige Experimente mit dreisprachigem Unterricht in Friesisch, Niederländisch und Englisch durchgeführt. Möglicherweise sind die Erkenntnisse aus diesen Experimenten auch für andere Fälle „weniger bedeutender" Minderheitensprachen lehrreich. Sowohl im Baskischen als auch im Friesischen gilt Mehrsprachigkeit allgemein als wichtige Kompetenz.

Resumen Educación multilingüe para lenguas minoritarias europeas: El País Vasco y Frisia - A lo largo de las tres últimas décadas, las lenguas regionales minoritarias han vuelto a recibir en Europa un creciente apoyo y reconocimiento. Su revitalización se debe, en parte, a que sean enseñadas en las escuelas. El multilingüismo tiene características especiales para quienes hablan lenguas minoritarias y supone un reto excepcional para el aprendizaje de lenguas minoritarias. Este artículo está dedicado a los casos del vasco y del frisio, comparando y contrastando sus similitudes y diferencias. El sistema educativo de la Comunidad Autónoma Vasca ha experimentado una transformación importante desde 1979, cuando menos del 5 por ciento de todos los docentes estaban capacitados para enseñar mediante la lengua vasca. Hoy, este porcentaje llega a superar el 80 por ciento. Se ha adoptado un enfoque innovador al enseñar la lengua minoritaria, el vasco, junto con la lengua dominante, el español, y el inglés como lengua internacional. El resultado es un incremento sustancial de conocimiento de la lengua minoritaria entre la gente más joven. Por lo tanto, el declive de la lengua minoritaria se ha revertido con éxito; ahora, uno de los mayores retos es mantener un sistema educativo sostenible. Por lo contrario, la lengua frisia ha prosperado menos en los Países Bajos, donde la evolución a lo largo de los últimos 30 años ha sido mucho más lenta, con resultados más modestos. Aquí, las políticas adoptadas para la educación y la lengua están atrapadas en un debate permanente entre un débil nivel provincial y un fuerte nivel de Estado central. En términos generales, el multilingüismo está bien valorado como recurso para las personas cuando se trata de lenguas "más importantes", tales como el inglés, el francés o el alemán, pero no para una lengua "menos importante" como 
el frisio. De todas maneras, se han realizado algunos experimentos trilingües en algunas escuelas de Frisia donde se ha enseñado frisio, holandés e inglés. Estos ensayos también pueden ser útiles para otros casos con lenguas minoritarias de "poder moderado". En los casos del vasco como del frisio, el multilingüismo se percibe, en líneas generales, como recurso importante.

Резюме Мультилингвальное образование и европейские языки меньшинств: страна басков и Фрисландия - На протяжении последних трех десятилетий региональные языки в Европе все больше получают признание и поддержку. Их восстановлению отчасти способствует их преподавание в школах. Мультилингвизм имеет особые характеристики для носителей языков меньшинств и создает отдельные проблемы в обучении языкам меньшинств. В данной статье рассматриваются примеры баскского и фризского языков, и выявляются их сходства и различия. Начиная с 1979 года, образовательная система в автономном сообществе басков претерпела существенные преобразования, когда менее 5\% всех учителей могли преподавать на баскском языке. В настоящее время этот показатель изменился и составляет более $80 \%$. Инновационный подход был выбран для преподавания языка меньшинства (баскского языка) наряду с доминирующим языком (испанским) и международным языком (английским). В результате наблюдается существенный рост освоения и владения языком меньшинства на уровне мастерства среди групп младшего возраста. Таким образом, угасание языка меньшинства было успешно преодолено, и одной из главных проблем в настоящее время является поддержание устойчивости образовательной системы. Напротив, фризский язык преуспел меньше в Нидерландах, где развитие на протяжении последних тридцати лет было намного медленнее, и результаты, соответственно, были более умеренными. Здесь образовательная и языковая политика находятся в постоянных дебатах между слабым периферийным и сильным центральным государственным уровнями. В целом, мультилингвизм, как ресурс для индивидов, ценится больше для «больших» языков, таких как английский, французский и немецкий языки, а не для такого «малого» языка, как фризский. Тем не менее, несколько трилингвальных экспериментов было проведено в некоторых школах во Фрисландии относительно преподавания фризского, голландского и английского языков. Данные эксперименты могут быть также полезны и для других языков меньшинств «средней силы». В обоих случаях с баскским и фризским языками мультилинвизм, в основном, рассматривается как важный ресурс.

Minority languages have been ignored to a large extent by speakers of majority languages. For minority language speakers themselves their languages are useful in everyday communication. However, minority languages differ in how far they are also used in other, more formal domains in society. Some minority languages, such 
as Basque, are used in a wide range of social fields. Other minority languages - and Frisian is a good example - have obtained a rather modest presence in domains such as government, the media, economic and social life. The Basque and Frisian language cases will be contrasted and taken as complementary in the discussion in this article. There are, of course, still other minority languages which are hardly used outside the sphere of the family and the home.

Efforts to revive minority languages usually begin with a focus on education. Compared to dominant languages, the use of minority languages in education is limited in most cases, but increasingly not just two but sometimes three and even four languages are used (Cenoz and Gorter 2005). The study of the teaching of minority languages can make a significant contribution to educational research. The teaching of minority languages is linked to many core areas of research, including first language (L1) literacy, second language acquisition, bilingualism and multilingualism, language and identity, language policy and the acquisition of additional languages. Analysing experience and the outcomes of research conducted in these settings can have implications for bi/multilingual education as well as for language learning and language acquisition in other educational settings.

\section{Minority languages in Western Europe}

Most of the population in Europe and North America are monolingual in one of the "big" languages, and these speakers are only exposed to other languages in the school context or through the media. This is not the case in many other parts of the world. Being monolingual is exceptional in the case of speakers of minority languages. In Western Europe, speakers of minority languages such as Basque and Frisian, but also others such as Catalan, Irish, Welsh, Friulian and Sámi, need to be multilingual. They all speak at least the majority language they are in contact with. In many cases, when the majority language is not English, they also need to have some command of English as the "language of wider communication". Minority language speakers are at least bilingual and learn additional languages at school (see also Busch 2011).

The multi-faceted constellation of languages of Europe comprises a range of minority languages (Extra and Gorter 2008). There are so-called "unique" minority languages, which are spoken in one or sometimes more than one state, but are not the dominant language of any state. These minorities may be extremely small and on the verge of extinction, such as Livonian in Latvia or Ume Sámi in Sweden, where the youngest speakers are over 60 years of age. The category also comprises language groups that have obtained official status, a fair degree of political and economic support and strong favourable attitudes by their speakers in order to revitalise these languages and give them a sustainable future.

Other language groups have a "kin-state". They are a minority in one state but the official dominant language in another, neighbouring state. Examples of such language groups are Albanian in Italy and Greece; Croatian in Italy and Austria and German in Belgium, the Czech Republic, Denmark, France, Italy and Poland. 
A few minority languages are official state languages, but in practice they function in sociological and economic terms largely in the same way as other minority languages. Such is the case of Luxembourgish, which is official in Luxembourg but has to compete with French and German, or Irish which is the first official language of the Irish Republic, but is dominated to a large extent by English. The 27 member states of the European Union share 23 official languages (European Commission 2007), among which is Irish, but not Luxembourgish. In a wider perspective we see that the 47 member states of the Council of Europe have 41 languages as official state languages. But these are still only a small subset of the estimated 195 language communities in Europe (Pan 2009).

\section{The case of Basque}

The Basque Country spreads along the Bay of Biscay, north and south of the Pyrenees in France and Spain. The population of the Basque Country is approximately three million and the most populated area is the Basque Autonomous Community (BAC) in Spain, with over two million inhabitants. Basque is completely different from French and Spanish and is the only non-Indo-European language in Western Europe. Nowadays Basque has approximately 600,000 speakers, all of whom are also fluent in either Spanish or French. Basque has an important literary tradition, but the unification of the Basque language into one standard for the written language is relatively recent. Today there is a rich literate environment. The written language can be "consumed" through one daily newspaper, numerous journals and magazines, thousands of books on a wide range of topics, omnipresence in public signage and advertisements and an uncountable number of Basque websites. At the same time the production of written materials in the majority language, Spanish, is many times higher and it has a dominant presence in Basque society.

According to a recent socio-linguistic survey (Basque Government 2008) there are important regional differences in levels of knowledge of Basque. In Table 1 we can see the percentages for knowledge of Basque in the BAC, in Navarre and in the area of Iparraldea in France.

The number of Basque speakers has increased slowly in the BAC over the last decades. The survey of 1991 showed that 24.1 per cent of the BAC was proficient in Basque; this increased to 27 per cent in 1996, further to 29.4 per cent in 2001 and to 30.1 per cent in the last survey. There is also a slight increase in Navarre (from 9.5

Table 1 Knowledge of Basque in the Basque Country according to sub-area (in percentages)

\begin{tabular}{lccc}
\hline & BAC & Navarre & Iparraldea \\
\hline Proficient in Basque & 30.1 & 11.1 & 22.5 \\
Passive skills in Basque & 18.3 & 7.6 & 8.6 \\
No knowledge of Basque & 51.5 & 81.3 & 68.9 \\
\hline
\end{tabular}

Source IV Inkesta Soziolinguistikoa (Basque Government 2008) 
per cent in 1991 to 11.1 per cent in 2006). However, the proportion of speakers in Iparraldea in France is decreasing (from 26.4 per cent in 1996 to 22.5 per cent in 2006).

There are important differences in the status of Basque in the three different areas. Since 1979 Basque has had co-official status in the BAC and there is a strong language policy. Basque is also official in the Northern area of Navarre (see Oroz and Sotés 2008). In Iparraldea in France, the status of Basque is much weaker. The language has a strong oral tradition as language of the community, but due to the robust language policy its use in more formal domains of society is also on the increase, in particular in the BAC. The rest of this article will focus on the BAC.

The use of Basque in education

In the BAC, three models of language schooling were established (models A, B and D).

- The A-model programme is intended for native speakers of Spanish who choose to be instructed in Spanish. Basque is taught as a subject for four to five hours a week. The outcome is minimal proficiency in Basque as a second language.

- The B-model programme is intended for native speakers of Spanish who want to be bilingual in Basque and Spanish. Both Basque and Spanish are used as languages of instruction for approximately 50 per cent of school time, although there is considerable variation from school to school (Arzamendi and Genesee 1997).

- The D-model programme was originally created for native speakers of Basque. Basque is the language of instruction, and Spanish is taught as a subject for four to five hours a week. This model currently also includes a large number of students with Spanish as their first language. The intensive use of Basque and the dominant position of Spanish in society lead to high levels of proficiency in both languages.

The distribution of students in the different models can be seen in Table 2 .

D-model, with Basque as the language of instruction, is the most popular, followed by B-model. Knowledge of Basque has an important value in society because it is required for many government-related jobs and has advantages in many jobs in the private sector as well. Because there is continuity from primary to secondary school, the use of Basque as the language of instruction in secondary

Table 2 Percentages of pupils in the different models in the BAC 2008-2009

\begin{tabular}{lclc}
\hline & A Spanish & B (Basque \& Spanish) & D Basque \\
\hline Primary (6-12) & $8.80 \%$ & $29.96 \%$ & $60.47 \%$ \\
Compulsory secondary (12-16) & $19.08 \%$ & $27.54 \%$ & $52.64 \%$ \\
\hline
\end{tabular}

Source Basque Government Department of Education (www.hezkuntza.net)

Note The percentages do not add up to 100 per cent because a limited number of students who stay in the BAC for a short period do not study Basque 
school is likely to increase in the near future when these children get older. Although there are some geographic differences related to the number of home language speakers of Basque, the D-model can be found all across the BAC, and parents have a choice in the type of school to which they send their child, although in small villages with relatively higher proportions of Basque speakers there is little or no demand for the A-model.

The increase in the use of Basque as the language of instruction over the last 30 years has had important implications for the educational system. Whereas in 1979 less than 5 per cent of all teachers were capable of teaching through the minority languages, today over 80 per cent of the teachers are able to use Basque (Zalbide and Cenoz 2008). To become a primary school teacher requires taking a four-year course at one of the teacher training colleges which are part of the university. An important part of the course includes teaching practice at primary schools. Secondary school teachers obtain a university degree in a particular subject and subsequently undergo a course of advanced teacher training (at Master degree level). In-service language training for Basque has been very important. Teachers who start without knowledge of Basque have the right to three years of full-time learning Basque, during which period they are released from teaching duties and keep their full pay. The BAC also has a strong system of teacher support centres.

The Department of Education in the BAC runs the Euskal Ikasmaterialgintza (EIMA) programme, whereby the Department subsidises learning materials to make sure that parents do not have to pay more for school materials in Basque because of the smaller market. School materials subsidised include books, wall charts, videos, software programmes and CD-ROMs, as well as learning materials via the internet. Awards are given annually to the best new materials, to promote quality. In this way the different publishing houses can offer a complete range of teaching and reference materials for primary and secondary education. Highly-specialised materials, for example for vocational training, are usually made available through the internet rather than in print.

The outcomes of bilingual education

There has been a large number of research studies and evaluations of bilingual education in the BAC (see Cenoz 2008). The results indicate that using Basque as the language of instruction results in a high level of proficiency in the second language, at no cost to people's first language proficiency or academic development. Among others it was shown that the results for the D-model school are better than for the B-model. Josu Sierra (2008) reports a study that took the Level B2 ("independent language user") of the Council of Europe as its point of departure. It was shown that pupils from the D-model scored significantly higher (68 per cent passed) in Basque than pupils from the B-model (32.6 per cent passed), whereas the test was too difficult for pupils from the A-model. Higher proficiency in the minority language is equivalent to a more balanced bilingualism because of the extended knowledge of Spanish. This knowledge of two languages provides some advantages when acquiring English as a third language. This effect can be explained 
as being related to a higher development of metalinguistic awareness and bilinguals' wider linguistic repertoire (see also Cenoz 2003).

The socio-linguistic context can have an important influence on language use. It is common for schoolchildren in Spanish-speaking areas to use Spanish among each other but Basque with the teacher; even in the D-model. There are special language policy plans for schools to promote the use of Basque (Aldekoa and Gardner 2002; Zalbide and Cenoz 2008), but the minority status of Basque in society cannot completely counterbalance the work done by schools.

The use of English in education

The Basque Country has also been affected by the worldwide spread of English as a language of wider communication and the increasing multilingualism and multiculturalism resulting from immigration.

English is not used much in everyday life in the BAC, but parents demand more instruction in English. The early introduction of English in kindergarten was an innovation in the educational system in the BAC from the 1990s. The idea is that more years of exposure to English will result in higher levels of proficiency. However, research carried out in the Basque Country shows that when exposure is limited (two to three hours per week) younger children do not necessarily make more progress than older children (see García Mayo \& García Lecumberri 2003; Cenoz 2009).

In the last few years, an increasing number of immigrants have been coming to the Basque Country. Immigrants make up 6.5 per cent of the population in the BAC and 12.2 per cent in Navarre (Instituto Nacional de Estadística 2008). Some of the immigrant students speak Spanish because they come from Spanish-speaking countries in Latin America, but the arrival of speakers of other languages creates a new challenge for a school system that already has three languages.

It is clear that the boundaries between the A, B and D models designed in the early 1980s are nowadays blurred because of the increasing number of Spanishspeaking students in the D model, the use of English as an additional language of instruction and the arrival of speakers of other languages.

Education evaluation policy

Basque students have been evaluated against the yardstick of an ideal monolingual speaker of Spanish and an ideal monolingual speaker of Basque. According to these evaluations, Basque L1 students who speak Basque at home, use Basque as the language of instruction and live in a Basque-speaking area attain a very good command of Spanish. However, it may be unrealistic that they achieve exactly the same level of proficiency in Spanish as other students who use Spanish for all purposes all the time, except for a very limited number of hours of Basque and English lessons at school (see Santiago et al. 2008). However, it would be better to evaluate students in the Basque educational system as multilingual speakers who have a linguistic repertoire which is different from that of monolinguals. A holistic view of multilingual proficiency as a reference is more challenging and difficult to 
put into practice in syllabus design, teaching practice and assessment, but it approaches the teaching of different languages from a more realistic perspective. Some innovative efforts in the direction of an integrated curriculum are being made in a limited number of schools (Elorza and Muñoa 2008).

\section{The case of Frisian}

The province of Friesland is located in the north of the Netherlands. It has almost 650,000 inhabitants. Frisian is a member of the branch of West-Germanic languages of the Indo-European language family. Although the languages are not mutually comprehensible, for a Dutch speaker it is relatively easy to learn to understand Frisian.

Dutch is the dominant language in society and in education as well. Frisian has not been able to obtain a substantial part of the central language functions in modern society, a fate it shares with many other minority languages (Extra and Gorter 2008, pp. 24-32). However, Frisian is still spoken by more than half of the population as their first language. It is used mainly in situations of informal communication in the family, the community and the lower work sphere. Inter-generational transmission of the language is at risk among younger parents (Foekema 2004). The results of language surveys over the past 40 years have shown a remarkable stability in the receptive skills of understanding and reading. As shown in Table 3, the ability to speak Frisian is gradually decreasing, whereas writing skills seem to have increased (Provinsje Fryslân 2007).

English can no longer be considered to be a foreign language in Friesland, but more of a second or a third language. People are confronted with English on an everyday basis through television, advertisements, internet and tourism. According to the Eurobarometer survey (2006) 87 per cent of the inhabitants of the Netherlands claim they are able to have a conversation in English. This proportion is similar to Sweden or Denmark, and more than double the average of the European Union.

The use of Frisian in education

Schools in Friesland are fully integrated in the centralised system of education in the Netherlands. The Frisian language has attained a marginal presence on all levels of education.

Playgroups and day-care centres (for children aged two to four) are left free in their choice of language. In most centres if children speak Frisian, in principle, they

Table 3 Proportion of the population competent in Frisian (percentages)

Source Provinsje Fryslân (2007, p. 5)

\begin{tabular}{lllll}
\hline Skill/year & 1967 & 1980 & 1994 & 2007 \\
\hline Understand & $97 \%$ & $94 \%$ & $94 \%$ & $94 \%$ \\
Read & $69 \%$ & $65 \%$ & $64 \%$ & $75 \%$ \\
Speak & $85 \%$ & $73 \%$ & $74 \%$ & $74 \%$ \\
Write & $11 \%$ & $10 \%$ & $17 \%$ & $26 \%$ \\
\hline
\end{tabular}


will be responded to in Frisian (except when the teacher cannot speak Frisian). Around 17 per cent of the age group participates in playgroups or centres for daycare that are wholly Frisian or systematically bilingual (Boneschansker 2006).

Primary schools are attended by children aged 4 to 12 (grades 1 to 8). All primary schools in Friesland have a legal obligation to teach Dutch, Frisian and English, the latter in the two highest grades. The most common pattern is to teach Frisian for half an hour per week as a subject in the two lowest grades and one full lesson in grades 3 to 8 , which equals a total of some 320 h over the whole primary school period. The overall situation for the teaching of Frisian as a subject has hardly changed since 1980 when Frisian was introduced as a compulsory subject. The position of Frisian is also modest as a medium of instruction for other subjects. In the lowest grades, 34 per cent of the schools use some Frisian for creative subjects and physical instruction. In the higher grades only 11 per cent of all primary schools use Frisian as a medium of instruction (Inspectie 2006, p. 32). English is taught as a subject for one lesson a week in the two highest grades. This is a general obligation in the Netherlands. There is no early introduction of English in Friesland thus far.

Secondary education has a core curriculum of 15 subjects, but schools are free to decide how much time they want to devote to each subject. Frisian is an obligatory subject in secondary education, but only 62 per cent of all schools do indeed offer Frisian (Inspectie 2006, p. 45). Frisian is only an optional subject in the higher grades. Dutch and English are taught as a subject in all schools. Sometimes German and French can be chosen as well.

At tertiary level there are three institutes of professional training in the capital, Ljouwert/Leeuwarden. The trend is to provide more courses through the medium of English. Although legally Frisian is allowed in oral exams or in writing a thesis, in practice its use is exceptional. Teacher training in Friesland is similar to that in the rest of the Netherlands in terms of its curriculum and quality control. The only additional qualification is that in teacher training for primary education students must follow a Frisian language course during the first two years of their training. Frisian is optional in the third year. By taking those courses, the students obtain a special certificate for Frisian.

The use of English in education

An experiment with trilingual education was set up to stimulate the teaching of Frisian. A basically bilingual model was developed (Ytsma 2000). Seven primary schools located in small villages with a total of approximately 400 pupils participated in the project (Ytsma 2002). In the model, 50 per cent of the teaching time is given to Frisian and the other 50 per cent to Dutch. English is introduced as a subject in the sixth grade (one year earlier than in other schools) and taught as a subject and used as language of instruction for a total of about 20 per cent of the time in the last two grades (Gorter 2005). The goal is to meet the attainment targets for both Frisian and Dutch to the full extent (which is not the case in most other schools). Moreover, the pupils have to reach a basic communicative ability in English (Van Ruijven and Ytsma 2008). The main difference between the trilingual 
schools and other primary schools in Friesland is in the larger amount of time taught through Frisian. Parents are consulted before a school adopts a trilingual programme and generally support the aim of trilingual competences for their children. Their involvement with the trilingual school is relatively high, but not substantially different from other schools in Friesland.

The results of the Trilingual Schools Project were not surprising. Hester Deelstra and Jehannes Ytsma (2005) compared the language background, language attitudes, vocabulary and reading skills in Frisian and in Dutch of students from the experimental trilingual schools and the control schools, which have Frisian as a subject for one hour per week. On most variables the differences in outcomes were small, but the students in the experimental schools scored higher on technical reading skills in Frisian. Bernie Van Ruijven and Jehannes Ytsma (2008) summarised the end results for the eight years of the longitudinal study. The differences between the experimental and the control schools were not significant for Dutch literacy, but on Frisian technical reading skills the children at the experimental schools scored higher. The reading and writing of Frisian is a relatively important part of the curriculum. The systematic bilingual approach had no negative influence on proficiency in the majority language and positive effects for the minority language.

Another important result was that literacy skills for English (reading and writing) differed very little between the schools. The aim of obtaining better literacy results in English was not fulfilled, although the children of the experimental schools showed more confidence in speaking English. After the experimental stage, the trilingual schools have become one of the focal points of provincial language policy.

\section{Educational language policy}

The position of Frisian in education remains rather weak because it is not seen as an important condition for socio-economic success. In general Frisian is not graded for the report card and when it is, it does not count for much (Van der Bij and Valk 2005). Still, the overall point of departure for Frisian as a minority language in society is favourable in terms of the relative number of speakers and the basic positive attitudes among the population, at least compared to many other minority languages in Europe (Nelde et al. 1996).

In Friesland, as elsewhere, multilingualism in society is increasing. Today many children come from mixed-language families. The number of immigrants (about 9.3 per cent so-called "Western" and "non-Western" immigrants) has increased, bringing a wide range of different home languages to the school (Centraal Bureau voor de Statistiek 2011), but this is not taken into account in the curriculum. In the classroom, the teacher will be confronted with this diversity and has to deal with a more complicated educational practice. In general, speaking different languages is valued positively, but minority languages such as Frisian or immigrant languages are lower on the prestige scale than English or other so-called modern languages such as French or German. 


\section{Both cases compared}

It has become clear that the two situations of Basque and Frisian have many important differences, but also share some characteristics, most of which they also have in common with other minority languages in Europe (see also Busch 2011).

\section{Differences}

Obviously Basque and Frisian do not have the same linguistic origin. Frisian is a Germanic language, but Basque is a non-Indo-European language of unknown origin. Thus, the linguistic distance between the minority language and the majority language(s) is not the same in these two cases. Basque is very different from Spanish and French, the Romance languages it is in contact with. Frisian is linguistically close to Dutch, also a Germanic language. The degree of official protection and promotion of these two languages is different. Basque is a co-official language (along with Spanish) in Spain but in France its legal status is much weaker. Frisian has obtained limited official recognition.

The extent to which both languages are used as the main language of instruction varies considerably. Basque has become the main language of instruction in the BAC but its use is not as strong in other areas where Basque is spoken. The position of Frisian in education is weaker and overall developments are slow.

The use of English presents another difference between the two situations. In both cases English is a third language in the school curriculum. But there are important differences between the more extensive use of English in society in Friesland and the more limited use of English in the Basque Country.

\section{Similarities}

There are several similarities between Basque and Frisian. Both are autochthonous languages, because they originate from the areas where they are still spoken today. They are "unique" in the sense of not being spoken in other states as a majority language. Both languages are in contact with a "stronger" language (Spanish and Dutch, respectively) and all speakers of the minority language are also fluent in the national language, which is also part of the school curriculum. Moreover, both languages are spoken in states that are members of the European Union (EU): Spain and the Netherlands. Thus their situations are influenced by the language policies of the EU and particularly of the Council of Europe through the European Charter for Regional or Minority Languages (Council of Europe 1992). The Charter is part of the legal framework to promote and protect the cultural heritage of languages in Europe (De Bot and Gorter 2005, p. 613). Both Spain and the Netherlands have signed and ratified the Charter, whereby different degrees of protection were promised. For Basque it added little to the level of promotion already offered by the regional governments. For Frisian the ratification and monitoring of the Charter has implied important moral support. The general policy on multilingualism as developed by the European Commission (2008) has hardly any direct impact on national or regional language policies in both cases, even though in society in 
general and in the education system in particular the value attached to multilingualism seems to be increasing.

\section{Common challenges}

The two situations have some challenges in common with other European minority languages. These two minority languages have obtained legal support and funding for their use in education even though there are important differences.

Minority languages such as Basque and Frisian face more problems than majority languages in the production of educational materials. The obvious reason is that there is a more limited market for learning materials. Moreover, minority languages often have a weak tradition in use as an academic language. Another challenge is the limited availability of qualified teachers. Usually there are fewer qualified teachers with a good command of a minority language than of a majority language. In some situations it may also be difficult to get specialised training to teach some specific minority languages or to teach through these languages.

Finally, modern society brings new challenges. The educational contexts of Basque and Frisian face new challenges deriving from the immigration of speakers of other languages, new technologies of communication, as well as the effects of tourism and globalisation. Schools nowadays have to be aware of these challenges and be prepared to teach for multilingualism.

\section{Research on minority languages}

Research on minority languages is not well known by speakers of "big" languages, but it is relevant to many areas (Cenoz and Gorter 2008). It can refer to situations of bilingual and multilingual education involving the use of minority, majority and foreign languages as languages of instruction. These situations include the spread of content-based instruction, also known as Content and Language Integrated Learning (CLIL), as an effective approach to language teaching in educational settings. Furthermore, minority languages in education can be of interest to researchers working on language policy and language planning or language assessment.

This discussion of Basque and Frisian focuses on the achievements of these minority languages in education in two different regions in Europe, but they may also be relevant for researchers elsewhere in Europe and on other continents worldwide. Teaching in minority languages is a dynamic process and faces new challenges. In this article we have presented two interesting cases and we suggest that a more holistic approach to research can be helpful in better understanding the diversity of a multilingual and multicultural world.

Acknowledgments This article is one of the outcomes of the work for the Donostia Research group on Education and Multilingualism (DREAM) supported by the Government of the Basque Country [BOPV 06.05.2010, p. 15]; and the project "La competencia plurilingüe en el contexto escolar" supported by the Spanish Ministry of Science and Innovation [grant number EDU2009-11601]. 
Open Access This article is distributed under the terms of the Creative Commons Attribution Noncommercial License which permits any noncommercial use, distribution, and reproduction in any medium, provided the original author(s) and source are credited.

\section{References}

Aldekoa, J., \& Gardner, N. (2002). Turning knowledge of Basque into use: Normalization plans for schools. International Journal for Bilingual Education and Bilingualism, 5, 339-354.

Arzamendi, J., \& Genesee, F. (1997). Reflections on immersion education in the Basque Country. In K. Johnson \& M. Swain (Eds.), Immersion education: International perspectives (pp. 151-166). Cambridge: Cambridge University Press.

Basque Government. (2008). IV Inkesta Soziolinguistikoa. Vitoria-Gasteiz: Basque Government.

Boneschansker, E. (2006). Evaluaasje Sintrum Frysktalige Berneopfang. Ljouwert: BBO.

Busch, B. (2011) Trends and innovative practices in multilingual education in Europe: An overview. International Review of Education, 57(5-6).

Cenoz, J. (2003). The additive effect of bilingualism on third language acquisition: A review. The International Journal of Bilingualism, 7, 71-88.

Cenoz, J. (Ed.). (2008). Teaching through Basque: Achievements and challenges. Language Culture and Curriculum, 21(1) (special issue).

Cenoz, J. (2009). Towards multilingual education. Bristol: Multilingual Matters.

Cenoz, J., \& Gorter, D. (2005). Trilingualism and minority languages in Europe. International Journal of the Sociology of Language, 171, 1-5.

Cenoz, J., \& Gorter, D. (Eds.). (2008). Multilingualism and minority languages: Achievements and challenges in education. AILA Review, 21. Amsterdam: Benjamins.

Centraal Bureau voor de Statistiek. (2011). Statline: Bevolking; leeftijd, herkomstgroepering, geslacht en regio, 1 januari. Accessed 9 Sept 2011, from www.statline.cbs.nl.

Council of Europe. (1992). European charter for regional or minority languages. Strasbourg: Council of Europe. Accessed 22 Sept 2009, from http://conventions.coe.int/Treaty/EN/Reports/Html/148.htm.

De Bot, K., \& Gorter, D. (2005). A European perspective on heritage languages. Modern Language Journal, 89, 612-616.

Deelstra, H., \& Ytsma, J. (2005). Onderzoeksresultaten groep 3 en 4 project Drietalige Basisschool; onderzoeksresultaten groep 5 en 6 project Drietalige Basissschool. Leeuwarden: Fryske Akademy (internal report).

Elorza, I., \& Muñoa, I. (2008). Promoting the minority language through integrated plurilingual language planning: The case of the Ikastolas. Language, Culture \& Curriculum, 21(1), 85-101.

Eurobarometer. (2006). Europeans and their languages, Special Eurobarometer 243-Wave 64.3 European Commission. Accessed 14 Nov 2011, from http://ec.europa.eu/languages/documents/ 2006-special-eurobarometer-survey-64.3-europeans-and-languages-report_en.pdf.

European Commission. (2007). Regulation no. 1 determining the languages to be used by the European Economic Community. Accessed 14 Nov 2011, from http://eur-lex.europa.eu/LexUriServ/site/en/ consleg/1958/R/01958R0001-20070101-en.pdf.

European Commission. (2008). Multilingualism: An asset for Europe and a shared commitment. Brussels: COM (2008) 566 final. Accessed 14 Nov 2011, from http://ec.europa.eu/languages/pdf/ com/2008_en.pdf.

Extra, G., \& Gorter, D. (2008). The constellation of languages in Europe: An inclusive approach. In G. Extra \& D. Gorter (Eds.), Multilingual Europe: Facts and policies (pp. 3-60). Berlin: Mouton de Gruyter.

Foekema, H. (2004). Overdracht van de Friese taal. Onderzoek in opdracht van Omrop Fryslân. Amsterdam: TNS/NIPO.

García Mayo, M. P., \& García Lecumberri, M. L. (Eds.). (2003). Age and the acquisition of English as a foreign language: Theoretical issues and field work. Clevedon: Multilingual Matters.

Gorter, D. (2005). Three languages of instruction in Fryslân. International Journal of the Sociology of Language, 171(2005), 57-73. 
Inspectie. (2006). Inspectie van het Onderwijs - De kwaliteit van het vak Fries in het basisonderwijs enhet voortgezet onderwijs in de provincie Fryslân. Utrecht: Inspectie van het Onderwijs.

Instituto Nacional de Estadística. (2008). Demografía y Población. http://www.ine.es. Accessed 9 Sept 2011.

Nelde, P., Strubell, M., \& Williams, G. (1996). Euromosaic: The production and reproduction of the minority language groups in the European Union. Luxemburg: Office for Official Publications of the European Communities.

Oroz, N., \& Sotés, P. (2008). Bilingual education in Navarre. Language, Culture and Curriculum, 21, 21-38.

Pan, C. (2009). Die Minderheitenfrage in der Europäischen Union. Europäisches Journal für Minderheitenfragen, 1, 20-31.

Province Fryslân. (2007). Rapportaazje fluchhifking Fryske taal. Leeuwarden/Ljouwert: ProvinsjeFryslân.

Santiago, K., Lukas, J. F., Moyano, N., Lizasoain, L., \& Joaristi, L. (2008). A longitudinal study of academic achievement in Spanish: The effect of linguistic models. Language, Culture and Curriculum, 21, 48-58.

Sierra, J. (2008). Assessment of bilingual education in the Basque Country. Language, Culture and Curriculum, 21, 39-47.

Van der Bij, J., \& Valk, R. W. (2005). Fries in het voortgezet onderwijs: een Echternachse processie. Een evaluatieonderzoek naar de effecten van het project $O p$ weg naar 'Fries als examenvak in hetvoortgezet onderwijs'. Sneek: Migg.

Van Ruijven, B., \& Ytsma, J. (2008). Trijetalige skoalle yn Fryslân. Onderzoek naar de opbrengsten van het drietalige onderwijsmodel in Fryslân. Leeuwarden: Fryske Akademy.

Ytsma, J. (2000). Trilingual primary education in Friesland. In J. Cenoz \& U. Jessner (Eds.), English in Europe: The acquisition of a third language (pp. 222-235). Clevedon: Multilingual Matters.

Ytsma, J. (2002). An experiment with trilingual primary education in Friesland. In D. Beetsma (Ed.), Trilingual primary education in Europe (pp. 51-58). Ljouwert: Fryske Akademy/Mercator Education.

Zalbide, M., \& Cenoz, J. (2008). Bilingual education in the Basque Autonomous Community: Achievements and challenges. Language Culture and Curriculum, 21, 5-20.

\section{The authors}

Durk Gorter is Ikerbasque research professor in the Faculty of Education of the University of the Basque Country in San Sebastian/Donostia, where he does work on multilingualism, European minority languages and linguistic landscapes. He was a researcher in the sociology of language at the Fryske Akademy in Ljouwert/Leeuwarden, The Netherlands, and also part-time full professor in the sociolinguistics of Frisian at the University of Amsterdam, with which he is still affiliated. Two recent edited books are Linguistic Landscape: Expanding the Scenery (with Elana Shohamy) and Multingual Europe: Facts and Policies (with Guus Extra).

Jasone Cenoz is Professor of Research Methods in Education in the Faculty of Education at the University of the Basque Country. Her research focuses on the acquisition of English as a third language, bilingualism, multilingualism and education. She is the editor (in collaboration with Ulrike Jessner) of the International Journal of Multilingualism. She is on the board of IAM (International Association of Multilingualism). In collaboration with other colleagues, she has edited several books on bilingualism and multilingualism. One of her recent publications is Towards Multilingual Education: Basque educational research in international perspective. 